\title{
Anxiolytic Essential Oils
}

\section{Damião Pergentino de Sousa*}

Department of Pharmacy, Federal University of Sergipe, São Cristóvão, Sergipe, Brazil

According to the World Health Organization [1], approximately 450 million people worldwide have some form of mental or behavioral disorder. One such disorder is anxiety, which is an emotional state that develops in response to real or imaginary threats and accordingly can be realistic or psychological [2]. A psychological crisis negatively affects daily activities and increases the risk for other disorders [3]. Anxiety disorders are among the most common forms of psychopathology worldwide [4], and the prevalence of anxiety as a medical condition has increased in recent years [5]. Since ancient times, essential oils of many plants, such as orange blossom, lemon balm, jasmine, and lavender, have been used in aromatherapy for their calming effects [6]. In recent decades, results of several scientific studies conducted in animals and humans have supported the use of these oils for psychoactive effects [7]. Studies on animal models of anxiety have successfully demonstrated the anxiolytic effects of essential oils, such as lavender [8], rose [9], and orange [10] oils. For example, the correlation between the chemical composition and anxiolytic activity of essential oils obtained from different Lavandula species has been established. Recently, it was demonstrated that the monoterpenes linalool and linalyl acetate acted synergistically in various plants of this species [11]. Linalool is the main constituent of the essential oil of Aniba rosaeodora Ducke, which has relaxing effects. Furthermore, studies in animals have shown that inhaled linalool has an anxiolytic effect, increases social interaction, and decreases aggressive behavior [12]. In another study, the specific physiological responses induced by linalool inhalation were investigated in human subjects exposed to experimental stress. The relaxing effects of linalool odorants were observed on certain physiological parameters related to stress conditions [13]. Anxiolytic activity of other oxygenated monoterpenes, such as carvone [14], 1,4-cineole [15], carvacrol [16], and isopulegol [17], was also demonstrated. Carvone is one of the constituents of Lippia alba responsible for its action as a tranquilizer [14]. Study of the mechanism of action of carvacrol revealed that this phenol acted via a gamma-aminobutyric acid (GABA)-benzodiazepine receptor complex [16]. In fact, the anxiolytic action of essential oils such as Cymbopogon citratus essential oil is mediated by the GABA receptor [18]. In other study, the anxiolytic-like property of Citrus aurantium L. essential oil was demonstrated in mice [10]. Limonene, a hydrocarbon monoterpene found in various bioactive essential oils, is the main chemical component (97.66\%) of this oil. Anxiolytic activity was also observed for essential oil of another type of orange, Citrus sinensis, which contained $54.48 \%$ limonene; this oil had psychoactive effects both in animals and in humans [19,20]. Recent studies have shown that inhaled (+)-limonene has an anxiolytic-like effect in animals [21]. Therefore, this chemical constituent should contribute to the anxiolytic activity of the plants of Citrus species. Pharmacological studies in animal models of anxiety have demonstrated the therapeutic potential of essential oils. However, for safe and effective therapeutic use of essential oils, more well-documented pre-clinical and clinical trials are necessary for the validation of their pharmacological actions and toxicity. Furthermore, standardization of pharmacological tests is essential to obtain reliable information about the therapeutic efficacy of these natural products as promoters of public health.

\section{References}

1. Sayers J (2001) The World Health Report 2001- Mental health: new understanding new hope. Geneva: WHO. Bull World Health Organ 79: 1085.

2. Barlow DH (1988) Anxiety and Its Disorders. Guilford Press, New York, NY.

3. Reardon LE, Leen-Feldner EW, Hayward CA (2009) Critical review of the empirical literature on the relation between anxiety and puberty. Clin Psychol Rev 29: 1-23.
4. Hellión-Ibarrola MC, Ibarrola DA, Montalbetti Y, Kennedy ML, Heinichen O, et al. (2006) The anxiolytic-like effects of Aloysia polystachya (Griseb.) Moldenke (Verbenaceae) in mice. J Ethnopharmacol 105: 400-408.

5. Andrews G, Sanderson K, Slade T, Issakidis C (2000) Why does the burden of disease persist? Relating the burden of anxiety and depression to effectiveness of treatment. Bull World Health Organ 78: 446-454.

6. Lawless J (2002) The encyclopedia of essential oils. The complete guide to the use of aromatic oils in aromatherapy, herbalism, health and well-being.

7. De Sousa DP (2012) Medicinal Essential Oils: Chemical, Pharmacological and Therapeutic Aspects. 1. ed. Nova Science Publishers, New York.

8. Shaw D, Annett JM, Doherty B, Leslie JC (2007) Anxiolytic effects of lavender oil inhalation on open-field behaviour in rats. Phytomedicine 14: 613-620.

9. Almeida RN, Motta SC, Faturi CB, Catallani B, Leite JR (2004) Anxiolytic-like effects of rose oil inhalation on the elevated plus-maze test in rats. Pharmacol Biochem Behav 77: 361-364.

10. Pultrini AM, Galindo LA, Costa M (2006) Effects of the essential oil from Citrus aurantium $\mathrm{L}$. in experimental anxiety models in mice. Life Sci 78: 1720-1725.

11. Takahashi M, Satou T, Ohashi M, Hayashi S, Sadamoto K, et al. (2011) Interspecies comparison of chemical composition and anxiolytic-like effects of lavender oils upon inhalation. Nat Prod Commun 6: 1769-1774.

12. Linck VM, da Silva AL, Figueiró M, Caramão EB, Moreno PR, et al. (2010) Effects of inhaled Linalool in anxiety, social interaction and aggressive behavior in mice. Phytomedicine 17: 679-683.

13. Höferl M, Krist S, Buchbauer G (2006) Chirality influences the effects of linalool on physiological parameters of stress. Planta Med 72: 1188-1192.

14. Hatano VY, Torricelli AS, Giassi AC, Coslope LA, Viana MB (2012) Anxiolytic effects of repeated treatment with an essential oil from Lippia alba and (R)-(-)carvone in the elevated T-maze. Braz J Med Biol Res 45: 238-243.

15. Gomes PB, Feitosa ML, Silva MI, Noronha EC, Moura BA, et al. (2010) Anxiolytic-like effect of the monoterpene 1,4-cineole in mice. Pharmaco Biochem Behav 96: 287-293.

16. Melo FH, Venâncio ET, de Sousa DP, de França Fonteles MM, de Vasconcelos SM, et al. (2010) Anxiolytic-like effect of Carvacrol (5-isopropyl-2-methylphenol) in mice: involvement with GABAergic transmission. Fundam Clin Pharmacol 24: 437-443.

17. Silva MI, de Aquino Neto MR, Teixeira Neto PF, Moura BA, do Amaral JF, et al (2007) Central nervous system activity of acute administration of isopulegol in mice. Pharmacol Biochem Behav 88: 141-147.

18. Costa CA, Kohn DO, de Lima VM, Gargano AC, Flório JC, et al. (2011) The GABAergic system contributes to the anxiolytic-like effect of essential oil from Cymbopogon citratus (lemongrass). J Ethnopharmacol 137: 828-836.

19. Faturi CB, Leite JR, Alves PB, Canton AC, Teixeira-Silva F (2010) Anxiolyticlike effect of sweet orange aroma in Wistar rats. Prog Neuropsychopharmacol Biol Psychiatry 34: 605-609.

20. Goes TC, Antunes FD, Alves PB, Teixeira-Silva F (2012) Effect of sweet orange aroma on experimental anxiety in humans. J Altern Complement Med 18: 798-804.

21. Lima NG, De Sousa DP, Pimenta FC, Alves MF, De Souza FS, et al. (2012) Anxiolytic-like activity and GC-MS analysis of (R)-(+)-limonene fragrance, a natural compound found in foods and plants. Pharmacol Biochem Behav 103: 450-454.

*Corresponding author: Damião Pergentino de Sousa, Department of Pharmacy, Federal University of Sergipe, São Cristóvão, Sergipe, Brazil, E-mail: damiao_desousa@yahoo.com.br

Received November 20, 2012; Accepted November 21, 2012; Published November 22, 2012

Citation: de Sousa DP (2012) Anxiolytic Essential Oils. Nat Prod Chem Res 1:e102. doi:10.4172/2329-6836.1000e102

Copyright: ( 2012 de Sousa DP. This is an open-access article distributed under the terms of the Creative Commons Attribution License, which permits unrestricted use, distribution, and reproduction in any medium, provided the original author and source are credited. 